\title{
PENYULUHAN MANAJEMEN SUMBER DAYA MANUSIA UNTUK PENGEMBANGAN KARANG TARUNA MEKARSARI RUMPIN BOGOR
}

\author{
${ }^{1}$ Mulyadi, ${ }^{2}$ Sutrisno, ${ }^{3}$ Hadi Winata, ${ }^{4}$ Paeno, ${ }^{5}$ Puji Harjianto \\ Dosen Fakultas Ekonomi Universitas Pamulang \\ Email: 1 dosen00031@unpam.ac.id
}

\begin{abstract}
ABSTRAK
Tujuan dari kegiatan pengabdian kepada masyarakat ini adalah untuk menumbuhkan jiwa wirausaha skala home industry untuk meningkatkat ekonomi keluarga masyarakat Desa Cidokom. Selain itu juga untuk menggerakkan masyarakat sekitar agar sadar menjaga kebersihan dan kesehatan lingkungan dengan sadar pengelolaan sampah yang baik dan benar.

Metode pengabdian dengan penyuluhan dan sumbang saran serta evaluasi dan ditutup dengan ramah tamah.

Hasil dari kegiatan ini adalah diharapkan kepada masyarakat agar terus berupaya meningkatkan produktivitas masyarakat dengan menyesuaikan potensi masyarakat setempat. Manajemen sumber daya manusia disajikan lebih dulu dengan pertimbangan pengetahuan ini merupakan dasar untuk dapat meningkatkan kualitas diri sebagai bekal untuk mencapai tujuan hidup
\end{abstract}

\section{Kata Kunci: Manajemen Sumber Daya Manusia, Pengembangan Karang Taruna}

\section{PENDAHULUAN}

Dewasa ini sumber daya manusia bukan semata-mata sumber daya, tetapi lebih dari aset bagi organisasi, atau istilahnya adalah human capital. Artinya, aset bernilai yang dapat dikembangkan sebagai investasi bagi organisasi. Manajemen sumber daya manusia sangat penting mengingat dengan perkembangan teknologi dan informasi saai ini cenderung mengkondisikan dalam menjalankan organisasi berdasarkan sistem atau lebih dikenal dengan Management by system. Keberadaan sumber daya manusia seakan ke geser tergantikan sistem, maka dari itu sebagai penggerak, dan pondasi dalam menjalankan organisasi posisi sumber daya manusia tidak boleh kalah dengan sistem. Sumber daya manusia harusnya yang menciptakan sistem untuk membantu memudahkan dan meringankan pekerjaan manusia bukan dikendalikan oleh sistem. Pada hakikatnya sumber daya manusia merupakan penggerak, pemikir, dan perencana untuk mencapai tujuan organisasi..

Permasalahnya, seiring dengan perkembangan teknologi yang seharusnya diimbangi dengan berkembangnya kualitas sumber daya manusia, pada riilnya masih banyak yang belum mampu beradaptasi dengan perkembangan teknologi tersebut, sehingga banyak organisasi yang kalah saing karena sumber daya manusia nya masih belum cukup kompeten. Seperti halnya organisasi social 
dalam masyarakat seperti Karang Taruna merupakan wadah membentuk dan membangun sumber daya manusia yang kompeten melalui organisasi masyarakat.

Karang Taruna Mekarsari yang berlokasi di Desa Mekarsari Kecamatan Rumpin Kabupaten Bogor merupakan salah satu karang taruna di berbagai wilayah, yang merupakan wadah menumbuhkan dan mengembangkan kualitas sumber daya manusia. Karang Taruna merupakan organisasi social yang beranggotakan para remaja, disini remaja dapat mengembangkan diri sesuai potensi masing-masing. Dan merupakan organisasi social dalam masyarakat sehingga perannya memang membantu masyarakat setempat. Untuk itu perlu pembinaan berkelanjutan agar para remaja tumbuh berkembang menjadi manusia dewasa yang berkualifikasi.

\section{METODE PELAKSANAAN KEGIATAN}

Adapun metode pelaksanaan program kemitraan masyarakat sebagai berikut:

1. Tahap Pemilihan Lokasi Pengabdian

Tahap pemilihan lokasi pengabdian kepada masyarakat tentu harus mempertimbangkan banyak hal., salah satunya adalah kebutuhan masyarakat yang merupakan objek dari pengabdian.

2. Tahap Pengusulan

Setelah tim pengusul melakukan observasi awal dan sudah mengidentifikasi permasalahan pada objek pengabdian kepada masyarakat, maka dapat ditentukan temanya atau judulnya.

3. Tahap Pengumpulan data

Pengumpulan data yaitu mengumpulkan data di lokasi pengabdian dengan melakukan konsultasi, observasi, wawancara, dan dokumentasi dengan menentukan strategi pengumpulan data yang dipandang tepat untuk menentukan tema atau fokus serta pendalaman data pada proses pengumpulan data berikutnya.

4. Tahap Persiapan Pelaksanaan

Tahap persiapan ini, dilakukan koordinasi secara intensif dengan anggota (tim) agar pelaksanaan kegiatan pengabdian kepada masyarakat dapat berjalan lancar. Persiapan materi penyuluhan, menyiapkan pemateri/narasumber, persiapan konsumsi, daftar hadir dan perlengkapan lain yang dibutuhkan terkait pelaksanaan kegiatan. Setelah semua sudah siap tentu juga perlu konfirmasi pada pemilik home industry akan hari, tanggal dan waktu pelaksanaan.

5. Tahap Pelaksanaan Pengabdian Kepada Masyarakat

Tahap pelaksanaan pengabdian kepada masyarakat merupakan tahap pelaksanaan penyuluhan tentang manajemen sumber daya manusia untuk pengembangan Karang Taruna Mekarsari Rumpin. Pada. tahap ini tim pengusul melakukan penyuluhan sesuai tema terkait, melakukan sharing pendapat, dan mengidentifikasi kebutuhan materi yang diinginkan dan penawaran program pengabdian kepada masyarakat berkelanjutan di masamasa yang akan datang. Langkah ini dilakukan tim pengusul agar program 
pengabdian kepada masyarakat ini berjalan lancar dan tepat sasaran sesuai dengan tujuan dilakukannya pengabdian kepada masyarakat.

6. Tahap Pelaporan Hasil Pengabdian

Pada tahan pelaporan hasil pengabdian kepada masyarakat ini merupakan laporan serangkaian kegiatan mulai dari surve pra pengabdian hingga pelaporan kegiatan.

\section{HASIL DAN PEMBAHASAN}

Karang taruna merupakan wadah pengembangan diri yang sangat positif mengingat dewasa ini sebagai dampak negative dari perkembangan teknologi informasi dan komunikasi sangat disayangkan jika para remaja terbawa arus pergaulan yang salah. Sudah banyak kejadian, akibat salah pergaulan para remaja lupa akan kewajiban dan tanggung jawabnya sebagai generasi penerus bangsa. Hal-hal semacam ini yang menyebabkan rendahnya kualitas sumber daya manusia. Semua tidak terlepas dari lingkungan yang membentuk karakter para remaja. Artinya, jika lingkungan pergaulannya salah maka akibatnya juga kurang baik. Lingkungan yang paling mendasar adalah lingkungan keluarga.dan masyarakat merupakan lingkungan sosialnya. Keluarga merupakan lingkungan terdekat untuk membesarkan, mendewasakan, dan di dalamnya mendapatkan pendidikan pertama kali. Karena itu keluarga mempunyai peran yang penting dalam perkembangan remaja. Keluarga yang baik akan memberikan pengaruh positif bagi remaja, sebaliknya keluarga yang kurang baik akan memberi pengaruh negatif.

Secara umum

Karang taruna merupakan suatu organisasi kepemudaan di Indonesia sebagai wadah pengembangan jiwa sosial generasi muda. Karang taruna tumbuh atas kesadaran dan rasa tanggung jawab sosial dari masyarakat dan untuk masyarakat itu sendiri khususnya generasi

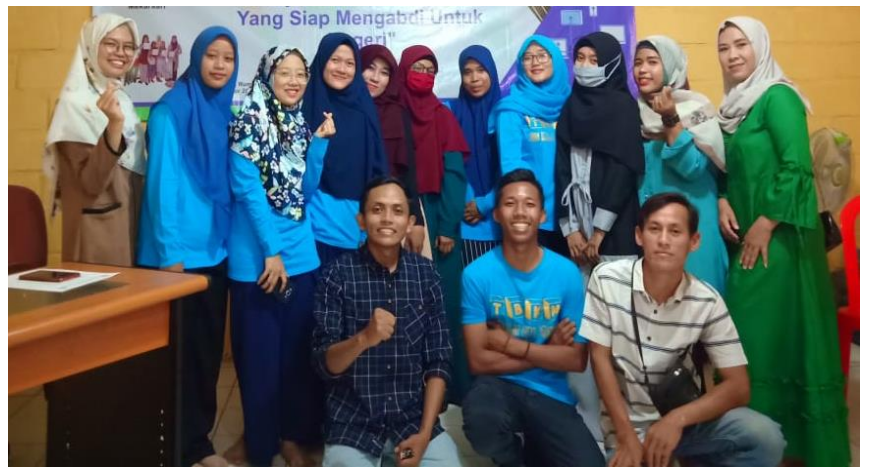
muda yang ada di suatu wilayah desa, kelurahan atau komunitas yang sederajat, terutama bergerak pada bidang-bidang kesejahteraan sosial (Wenti, 2013). Seperti bidang ekonomi, olahraga, keterampilan, keagamaan dan kesenian sesuai dengan tujuan didirikannya karang taruna untuk memberikan pembinaan dan pemberdayaan kepada para remaja di suatu desa atau wilayah itu sendiri. Sebagai organisasi sosial kepemudaan Karang Taruna merupakan wadah atau tempat pembinaan dan pengembangan dalam upaya mengembangkan kegiatan ekonomi, sosial, budaya dengan memanfaatankan semua potensi yang ada di lingkungan masyarakat, baik sumber daya manusia maupun sumber daya alam yang telah tersedia. 
Begitu halnya Karang Taruna Mekarsari merupakan wadah atau organisasi kepemudaan ditingkat Rukun Warga (RW) di Desa Mekarsari guna mewadahi kegiatan remaja putra putri untuk mengembangkan minat bakatnya melalui program kegiatan yang diagendakan oleh pengurus yang disusun melalui program

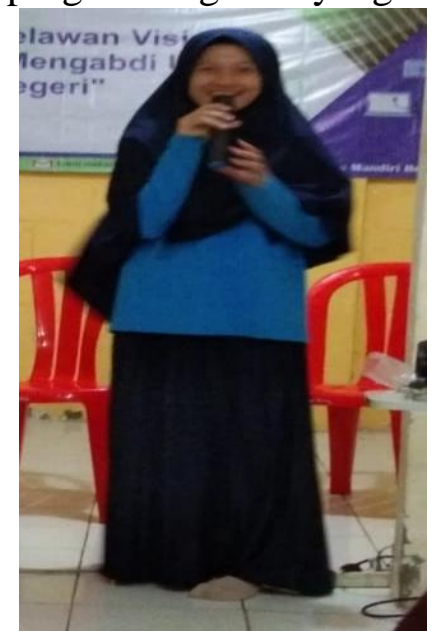
kerja. Itulah sebabnya subyek dari kegiatan pengabdian kepada masyarakat ini adalah Karang Taruna Mekarsari Rumpin Bogor dimana anggota Karang Taruna merupakan bagian dari masyarakat sebagai penyambung lidah untuk diteruskan kepada keluarganya ataupun masyarakat luas. Pertimbangan lainnya, karena keanggotaan dari Karang Taruna adalah remaja atau pemuda, selain memberikan kegiatan yang positif juga dirasa perlu untuk mendapatkan tambahan pengetahuan, ketrampilan dan pengarahan dalam rangka menyiapkan generasi penerus bangsa yang berkualitas.

Desa Mekarsari Kecamatan Rumpin merupakan bagian dari wilayah kabupaten Bogor yang bisa dibilang masih tergolong madya, artinya masyarakatnya masih belum maju dan perlu perhatian dari pemerintah daerah setempat. Secara structural desa merupakan pemerintahan terkecil dari suatu Negara. Untuk membangun desa diperlukan membangun sumber daya manusia terlebih dahulu, karena sumber daya manusia merupakan pondasi dan penggerak dari suatu organisasi. Maju tidaknya suatu wilayah tergantung pada sumber daya manusianya. Jika dalam suatu masyarakat sumber daya manusia produktif maka daearh tersebut juga akan lebih maju dibanding dengan daerah yang sumber daya manusia kurang produktif atau kurang berkualitas. Berkembang tidaknya suatu Negara dapat dicerminkan dari maju tidaknya wilayah desa, artinya kalau desanya maju dan makmur pasti wilayah di atasnya seperti kecamatan, kota, propinsinya juga maju dan makmur. Maka dari itu kemakmuran suatu Negara juga dapat diukur dari tingkat kemamkmuran desanya. Itulah sebabnya perlu bersinergi dalam membangun desa antar aparat pemerintah desa dengan masyarakat setempat untuk bersama-sama berkolaborasi membangun dan memajukan desanya, dalam hal ini adalah Desa Mekarsari.

Kepengurusan Karang Taruna Mekarsari Rumpin dilakukan pergantian secara berkala periode tiga tahunan itu merupakan organisasi social yang kegiatannya berdasarkan hasil rapat kerja untuk menyusun program-program sesuai dengan perkembangan wilayah Desa Mekarsari Rumpin. Pemilihan yang melibatkan ketua RT dan RW baru pertama kali dilakukan, sebelumnya dengan cara musyawarah besar bersama Kepala Desa dan tokoh pemuda. Pemilihan Ketua Karang Taruna dilakukan pada Minggu, 14 Oktober 2018 untuk periode 2018 2021. Pola pemilihan seperti ini mendapat apresiasi dari Kepala Desa karena mencerminkan proses pemilihan secara demokrasi, penuh kebersamaan guna bersama-sama, berkolaborasi dan bersinergi membangun Desa Mekarsari. Hendra Wahyudi sebagai ketua terpilih juga menyampaikan bahwa pemuda pemudi 
melalui wadah karang taruna bisa bekerja sama untuk memajukan Desa Mekarsari Rumpin. Hendra Wahyudi bersama timnya yang beranggotakan 38 remaja telah berkomitmen mengembangkan dan memajukan Desa Mekarsari bersama masyarakat.

Berdasarkan peran dan fungsi Karang Taruna Mekarsari Rumpin yang banyak membantu dan berkontribusi pada masyarakat, sudah selayaknya dapat perhatian dari semua pihak agar organisasi karang taruna dapat menjalankan peran dan fungsinya secara optimal. Apalagi anggotanya adalah para remaja yang secara kepribadian juga belum dapat dikatakan matang, dengan kata lain belum stabil, sehingga masih mudah dipengaruhi. Dengan mereka aktif dalam ke organisasian seperti karang taruna akan sangat membantu pembentukan karakter kepemimpinan yang mempunyai tanggung jawab, dedikasi yang tinggi, bekerja dengan tim dan berani mengambil risiko. Pembentukan karakter harus dimulai dari dini, artinya mulai anak-anak perlu ditumbuhkan dasar-dasar kepemimpinan dan kerja tim. Karang taruna merupakan alternative yang tepat untuk tumbuh kembang remaja untuk memberikan kegiatan positif agar tidak terbawa arus pergaulan yang salah.

\section{KESIMPULAN DAN SARAN}

Hasil dari kegiatan ini adalah diharapkan kepada masyarakat agar terus berupaya meningkatkan produktivitas masyarakat dengan menyesuaikan potensi masyarakat setempat. Manajemen sumber daya manusia disajikan lebih dulu dengan pertimbangan pengetahuan ini merupakan dasar untuk dapat meningkatkan kualitas diri sebagai bekal untuk mencapai tujuan hidup. Seseorang yang sudah matang pola pikir atau memiliki kemampuan menyikapi hidup secara efektif dan efisian cenderung lebih memiliki daya tahan untuk menghadapi segala permasalahan.

\section{DAFTAR PUSTAKA}

Handoko, Hani. 2012. Manajemen Personalia dan Sumber Daya Manusia Edisi 2. BPFE Yogyakarta.

Sunasi, D., Kusjono, G., \& Nuryana, I. (2019). Pelatihan Manajemen Penguasaan Kelas Dan Pembuatan Bahan Ajar Bagi Tenaga Pengajar Sukarela Taman Belajar Kreatif Mekarsari. Jurnal Pengabdian Dharma Laksana, 2(1), 4144.

Sutrisno, 2014. Manajemen Sumber Daya Manusia. Kencana Predana Media Group. Jakarta 